\title{
Penerapan Zachman Framework Dalam Perancangan Sistem Informasi Manajemen Keuangan Sekolah
}

\author{
Rizal Fahmi Awaludin', Saeful Bahri², Muhamad Muslih ${ }^{3}$ \\ Program Studi Sistem Informasi, Fakultas Teknologi Informasi dan Komputer, Universitas Nusa Putra \\ J1. Raya Cibolag No 21 Sukabumi, Jawa Barat, Indonesia 43152 \\ ${ }^{1}$ rizal.fahmi_si17@nusaputra.ac.id, 25aeful.bahri_si17@nusaputra.ac.id, ${ }^{3}$ muhamad.muslih@nusaputra.ac.id
}

\begin{abstract}
Abstrak-Sekolah swasta tidak terlepas dari sumber pendanaan dari siswa maupun dari bantuan operasional sekolah, pendanaan yang diterima sekolah tentunya memiliki kegunaan yang berbeda- beda sesuai dengan peruntukan dana tersebut dibayarkan oleh siswa maupun dari bantuan operasional sekolah, sehingga dalam proses pencatatan dan pengelolaan dana tersebut diperlukan ketelitian supaya tidak terjadinya kesalahan dalam proses pembuatan laporan keuangan disetiap akhir periode. sehingga sekolah memerlukan suatu sistem dalam pengelolaan hal tersebut. Kemajuan zaman yang semakin modern menjadikan suatu sistem aplikasi otomasi dan terintegrasi tidak hanya sebagai nilai tambah tetapi menjadi sebuah kebutuhan dalam menjalankan suatu organisasi. Menanggapi hal ini peneliti mencoba menggambarkan suatu rancangan sistem informasi manajemen keuangan yang bisa digunakan sesuai dengan keperluan sekolah dengan menggunakan kerangka kerja arsitektur enterprise yaitu zachman framework yang bisa membantu dalam proses pembuatan sistem keuangan sekolah ini, rancangan sistem atau blueprint sistem ini mengedepankan pandangan dari berbagai persektif yang ada di sekolah dan dijadikan sebagai acuan dalam pembuatan sistem ini sehingga sistem bisa dirancang sesuai dengan kebutuhan dan masalah yang di hadapi sekolah khususnya dalam pengelolaan keuangannya, dalam pengambilan data yang dibutuhkan peneliti melakukan observasi dan wawancara langsung ke lokasi penelitian yaitu SDIT Andalusia dan dalam pengelolaan keuangan masih terdapat beberapa kesalahan seperti redudansi data, kesalahan penulisan dan pencatatan dikarenakan masih menggunakan pencatatan manual, sehingga dalam penyusunan laporan keuangan sering terjadi keslahan jika tidak teliti dalam melakukan penyusunan tersebut. Dalam penelitian ini penulis hanya memuat empat persfektif yang ada dalam kerangka zachman diantaranya yaitu: perspektif planner, perspektif owner, perspektif designer dan perspektif builder. Hasil dari penelitian ini berupa suatu rancangan suatu sistem informasi keuangan yang dapat digunakan sebagai acuan dalam pembuatan suatu aplikasi sistem informasi keuangan yang cocok digunakan oleh sekolah, sehingga dikemudian hari bisa digunakan sebagai sarana untuk mempermudah dan mengatasi kesalahan kesalahan yang sering terjadi dalam proses pencatatan keuangan dan pencatatan laporan keuangan di sekolah.
\end{abstract}

Kata kunci: Sistem Informasi, Zachman Framework, Keuangan Sekolah, Arsitektur Enterprise, Rancangan Sistem.

\begin{abstract}
Private schools are not independent of funding sources from students nor from school operational assistance, funding received by schools certainly have different uses different according to the appropriation of such funds paid by students and from school operational assistance, so in the process of recording and managing such funds required rigor in order that no errors occurred in the process of making financial reports at the end of the period. so that schools require a system in the management of that. The increasingly modern advance of the age makes a system of automation and integrated applications not only as value added but into a necessity in running an organization. In response to this researcher tried to describe a design of financial management information systems that could be used according to school purposes using the enterprise architecture framework that is zachman framework that could help in the process of creating this school financial system, design or blueprinting this system put forward a view of the various objectives that exist in schools and be made a reference to the creation of this system so that the system could be designed according to the needs and problems that the school faces in particular in its financial management, in the data retrieval that researchers need to make direct observations and interviews to research sites, namely the Andalusian SDIT and in financial management there are still some mistakes such as data redundancy, writing errors and record keepings are because they still use manual record keeping, so in the preparation of financial reports often occurring laxity if not meticulous in doing such drafting. In this study the author contained only four perfectives present in the zachman framework of which were: planner perspective, owner perspective, designer perspective and builder perspective. The result of the study was in the form of a design of a financial information system that could be used as a reference in the creation of an application of suitable financial information systems used by schools, so that later in life it could be used as a means to ease and overcome frequent errors in financial recording processes and record keeping financial statements in schools.
\end{abstract}

Keywords: Information System, Zachman Framework, School Finance, Enterprise Architecture, System Design.

\section{PENDAhuluan}

Sebuah organisasi sejatinya memiliki sebuah sistem yang digunakan dalam menjalankan kegiatan operasional organisasi tersebut. Organisasi ialah keseluruhan perpaduan unsur manusia dan non manusia yang masing-masing meiliki fungsi dalam mencapai tujuan[1]. Sistem ialah kumpulan elemen serta prosedur yang beriteraksi dalam suatu jaringan kerja yang memiliki tujuan untuk menyelesaikan suatu sasaran tertentu. Untuk mencapai sasaran tertentu suatu organisasi membutuhkan berbagai sumber informasi untuk menunjang kegiatan kegiatan yang 
dilakukan oleh elemen elemen yang terdapat dalam sebuah sistem tersebut. Informasi yaitu data yang telah diolah menjadibentuk yang lebih berguna dan memberikan manfaat lebih bagi yang menerimanya[2].

Sistem informasi ialah suatu sistem yang menyajikan informasi yang bertujuan untuk mengambil suatu keputusan dan menjalankan kegiatan operasional suatu organisasi dan memberikan suatu keunggulan kompetitif,[3] sistem terbentuk dari tergabungnya orang-orang, teknologi informasi dan prosedur-prosedur yang terorganisasi. Aplikasi sistem merupakan salah satu bagian dari sistem informasi yang digunakan sebagai alat penunjang kegiatan disuatu organisasi guna salah satu alat untuk mempermudah proses kegiatan bisnis suatu organisasi. Sistem informasi yang digabungkan dengan sebuah teknologi komputer akan menghasilkan suatu teknologi informasi yang bermanfaat dan efisien dalam mengelola informasi yang menjadi sumber kegiatan dalam sebuah proses bisnis yang ada didalam organisasi.

Di era sekarang menggunakan teknologi informasi dan sistem informasi dalam sebuah lembaga merupakan bentuk respon dari perkembangan zaman yang semakin pesat guna menunjang kelancaran dalam kegiatan operasional suatu organisasi[4], maka dalam suatu organisasi teknologi informasi dan sistem informasi menjadi salah satu hal yang penting dalam menjalankan suatu proses bisnis organisasi atau lembaga tersebut supaya lebih efisien dalam pelaksanaannya.

Manajemen keuangan sekolah yaitu suatu cara pengaturan dan pertanggung jawaban atas penggunaan segala jenis penggunaan keuangan yang diterima dari peserta didik[5]. Manajemen keuangan di sekolah merupakan suatu hal yang penting dikarenakan keuangan merupakan salah satu sumber dana untuk menjalankan kegiatan operasional lembaga maka diperlukan manajemen atau pengaturan yang baik dalam menjalankannya supaya kegiatan yang dilakukan berjalan sesuai dengan tujuan yang ingin dicapai.

Arsitektur enterprise digunakan untuk mendesain dan merealisasikan sebuah struktur organisasi enterprise, struktur organisasi, sistem informasi dan sistem infrastrukturnya dan merupakan suatu kumpulan prinsip, metode dan model yang bersifat masuk akal[6]

Dalam merancang sebuah sistem akan lebih tertata ketika menggunakan suatu kerangka kerja, Zachman framework merupakan salah satu kerangka arsitektur enterprise yang berguna untuk mempermudah dalam pemetaan suatu aplikasi sistem informasi sehingga sesuai dengan perspektif dari masing-masing elemen yang ada dalam lembaga[7].

Sealin itu Zachman Framework merupakan teori model Enterprise Architecture, sebagai tool yang berfungsi untuk mengategorikan deliverables untuk menggambarkan Enterprise Architecture sepenuhnya dan banyak diadopsi oleh perusahaan di seluruh dunia. Zachman Framework juga menyediakan cara berpikir yang terstruktur mengenai enterprise dalam hal sistem informasi, sehingga sistem informasi dapat dijelaskan secara lebih detail dan persyaratan ditentukan dari berbagai sudut pandang berbeda[8], dan dapat menghasilkan sistem informasi yang sesuai dengan apa yang dibutuhkan oleh organisasi atau lembaga tersebut.

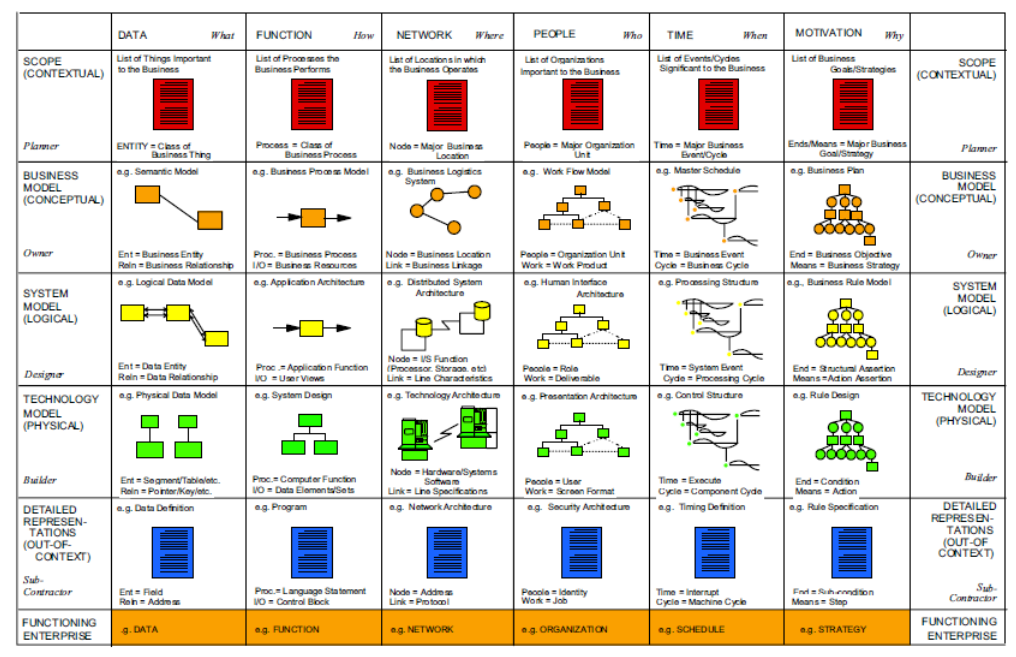

Gambar 1. Zachman framework

SD Islam Terpadu Kota Sukabumi merupakan salah satu lembaga pendidikan swasta yang didirikan pada tahun 2014 berlokasi di Kota Sukabumi, sehingga dalam pelaksanaan operasional lembaga pendanaannya didapat dari peserta didik dan hal tersebut menimbulkan pos-pos keuangan yang banyak dan harus diolah dengan manajemen keuangan yang baik, saat ini pencatatan pendapatan pada lembaga menggunakan sofware aplikasi Ms. Excel dan penulisan manual dibeberapa pos keuangannya. Sehingga dalam penyusunan laporan dikhawatirkan data dari aplikasi dan pencatatan manual melalui Ms. Excel tidak sesuai dan terjadinya redudansi data yang mengakibatkan laporan keuangan mengalami kesalahan. Perancangan sistem pengelolaan keuangan yang tepat menjadi kunci penting dalam mengatasi masalah ini. 
Oleh karena itu, dibutuhkan sebuah kerangka kerja yang bisa mengakomodasi kepentingan-kepentingan dari pihak yang terlibat didalam proses pencatatan dan pelaporan keuangan dan mengidentifikasi setiap aspek yang diperlukan dalam sistem tersebut. Salah satu kerangka kerja yang dapat melihat setiap permasalahan dalam merancang arsitektur enterprise dari berbagai perspektif adalah Zachman framework.

Zachman framework merupakan salah satu dari metode untuk mempermudah merancang suatu arsitektur enterprise yang mendukung semua pihak manajemen dalam mendefinisikan sebuah sistem yang dibutuhkan sehingga memiliki struktur dasar sistem informasi yang menunjukan sistem informasi dari beberapa sudut pandang yang menjalankan kompleksitas dan mempromosikan perencanaan, perancangan, dan manajemen konfigurasi. Zachman framework memnadang informasi dari enam aspek utama diantaranya : Data, Fungsi, Jaringan, Orang, Waktu dan Motivasi. Dan enam perspektif yang berbeda yaitu : Planner, Owner, Designer, Builder, Sub-Contractor dan Fuctioning Enterprise.

Pada penelitian ini diusulkan suatu bentuk rancangan aplikasi sistem yang berfokus pada bagian keuangan di lembaga dengan tujuan untuk memberikan gambaran dalam membuat suatu aplikasi sistem yang cocok digunakan untuk mengatasi hal hal yang berkaitan dengan manajemen keuangan sekolah, dengan menggunakan zachman framework sebagai kerangka pembuatan arsitektur enterprisenya diharapkan bisa memberikan gambaran aplikasi sistem yang diinginkan oleh pihak pihak terkait. Sejumlah penelitian yang dijadikan rujukan mengenai zachman framwork diantaranya yaitu : 1) Analisa dan perancangan sistem informasi penerimaan siswa baru dan pembayaran spp menggunakan zachman framework[9], 2) Penerapan framework zachman dalam merancang blueprint (arsitektur) sistem informasi administrasi pada koperasi simpan pinjam jaya manunggal semarang[10] .

Hasil yang diharapkan dari penelitian ini adalah terciptanya blueprint suau aplikasi sistem informasi keuangan yang sesuai dengan yang dibutuhkan oleh lembaga khususnya di bidang keuangannya yang dijadikan fokus pembahasan dalam pembuatan sistem dengan menggunakan kerangka zachman ini.

\section{METODE PENELITIAN}

Dalam penelitian ini pendekatan yang digunakan yaitu berfokus pada penerapan zachman framework untuk menganalisis sistem informasi manajemen keuangannya. Penelitian dilakukan dengan beberapa metode untuk mendapatkan data dari sumber daya manusia yang berkaitan dengan penelitian ini. Penelitian dimulai dari tahap pendahuluan, yaitu menyusun terlebih dahulu latar belakang dan rumusan masalah. Kemudian melakukan kajian Pustaka dengan mengumpulkan informasi-informasi yang berhubungan yang dibutuhkan untuk penelitian. Selanjutnya membuat perencanan menentukan baik ruang lingkup, sasaran, visi, penentuan metodologi dan alatalat yang akan digunakan. Kemudian dilanjutkan dengan pemetaan zachman framework dimulai dari perspektif perencanaan, pemilik, designer dan builder secara berturut-turut dengan menggunakan seluruh kolom yang tersedia yaitu $5 \mathrm{w}+1 \mathrm{~h}$. Tahap selanjutnya menganalisa hasil dan rancangan aplikasi dengan melakukan analisa berdasarkan data yang telah dikumpulkan. Yang terakhir rencana implementasi, setelah perancangan selesai dibuat maka akan dilanjutkan ke perencanaan implementasi.

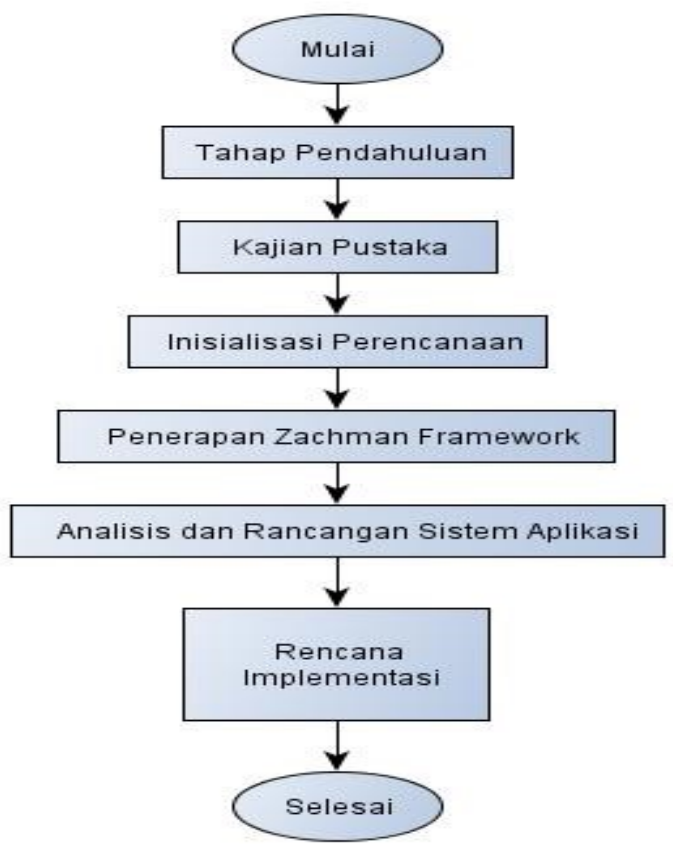

Gambar 2. Tahap penelitian 


\subsection{Wawancara}

Bertanya langsung kepada pihak pihak yang dapat memberikan informasi yang dibutuhkan merupakan cara yang digunakan dalam metode ini. Wawancara (interview) dilakukan untuk mendapatkan informasi, yang tidak dapat diperoleh melalui observasi atau kuesioner. Ini disebabkan oleh karena peneliti tidak dapat mengobservasi seluruhnya. Tidak semua data dapat diperoleh dengan observasi. Oleh karena itu peneliti harus mengajukan pertanyaan kepada partisipan. Pertanyaan sangat penting untuk menangkap persepsi, pikiran, pendapat, perasaan orang tentang suatu gejala, peristiwa, fakta atau realita. Dengan mengajukan pertanyaan peneliti masuk dalam alam berpikir orang lain, mendapatkan apa yang ada dalam pikiran mereka dan mengerti apa yang mereka pikirkan. Karena persepsi, perasaan, pikiran orang sangat berarti, dapat dipahami dan dapat dieksplisitkan dan dianalisis secara ilmiah.[11]. Peneliti melakukan wawancara dengan sumber daya manusia (SDM) yang ada di lembaga yang menjadi tempat penelitian, diantaranya yaitu pihak yayasan, staff pembayaran dan SDM yang berkaitan dengan penelitian.

\subsection{Observasi}

Peneliti mengamati secara langsung kegiatan yang berkaitan dengan objek penelitian guna mendapatkan data yang akurat. Metode ini memungkinkan untuk mengamati kenyataan dari sudut pandang subjek. Metode ini digunakan untuk mencari data bagaimana kinerja dari aplikasi dalam menunjang kemudahan untuk pelaksanaan penelitian [12]. Observasi juga diartikan sebagai kegiatan yang melibatkan seluruh kekuatan indera seperti pendengaran, penglihatan, perasa, sentuhan dan cita rasa berdasarkan pada fakta-fakta peristiwa empiris[13]. Hasil pengamatan yang dilakukan dapat membantu memberikan gambaran suatu proses bisnis yang berjalan dilembaga sehingga melengkapi data yang tidak diperoleh dalam wawancara.

\subsection{Kepustakaan}

Menghimpun data-data dari hasil pencarian dan pemahaman melalui buku-buku maupun penelitian-penelitian yang berkaitan dengan penelitian. Referensi yang digunakan dapat dilihat pada daftar Pustaka. Studi pustaka menempati posisi yang sangat penting dalam penelitian. Walaupun sebagian orang membedakan antara riset kepustakaan dan riset lapangan, akan tetapi keduaduanya memerlukan penelusuran pustaka. Ada perbedaan yang melekat pada riset kepustakaan dengan riset lapangan, perbedaannya yang utama adalah terletak pada tujuan, fungsi atau kedudukan studi pustaka dalam masing-masing penelitian tersebut. Riset lapangan, penelusuran pustaka sebagai langkah awal dalam rangka untuk menyiapkan kerangka penelitian yang bertujuan memperoleh informasi penelitian sejenis, memperdalam kajian teoritis. Sementara dalam riset pustaka, penelusuran pustaka lebih daripada sekedar melayani fungsi-fungsi yang disebutkan untuk memperoleh data penelitiannya. Tegasnya riset pustaka membatasi kegiatannya hanya pada bahan-bahan koleksi perpustakaan saja tanpa memerlukan riset lapangan[14]. Kepustakaan yang dilakukan lebih melihat sumber materi yang berkaitan dengan penelitian seperti mempelajari sistem informasi dan arsitektur enterprise khususnya metode zachman framework.

\subsection{Zachman framework}

Zachman Framework adalah framework Arsitektur Enterprise yang menyediakan cara untuk memandang dan mendefinisikan sebuah enterprise secara formal dan terstruktur dengan baik. Framework ini Merupakan matrik $6 \times 6$ yang didalamnya terdiri dari baris perspektif dan di deskripsikan dengan kolom pertanyaan $5 \mathrm{~W}$ dan $1 \mathrm{H}$ yaitu : 1) What (data) : menggamabarkan kesatuan yang dianggap penting dalam bisnis. Kesatuan tersebut adalah halhal yang informasinya perlu dipelihara. 2) How (fungsi) : mendefinisikan fungsi dan aktifitas. Input dan output juga dipertimbangkan di kolom ini. 3) Where (jaringan) : menunjukkan lokasi geografis dan hubungan antara aktifitas dalam organisasi, meliputi lokasi geografis bisnis yang utama. 4) Who (manusia) : mewakili manusia dalam organisasi dan metrik untuk mengukur kemampuan dan kinerjanya. 5) When (waktu) : mewakili waktu dan menunjukkan kriteria kerja. Kolom ini berguna untuk mendesain jadwal dan memproses arsitektur. 6) Why (motivasi) : menjelaskan motivasi dari organisasi dan pekerjaannya. Disini terlihat tujuan, sasaran, rencana bisnis, arsitektur pengetahuan, alasan pikiran dan pengambilan keputusan dalam organisasi [15]. Adapun baris perspektifnya yaitu : 1) Perspektif perencana (Objective/Scope): menjelaskan segala model bisnis funsional secara keseluruhan diantaranya konteks bisnis, latar belakang dan tujuan, 2) Perspektif pemilik (Enterprise Model): mendefinisikan segala model proses bisnis,fungsi bisnis, menurut pandangan dari pemilik atau owner, 3) Perspektif perancang (System Model): memuat segala model logika, manajemen proyek dan pendefinisian kebutuhan berdasarkan perspektif desainer dan menjembatani keinginan pemilik sehingga bisa direalisasikan secara teknis dan fisik, 4) Perspektif builder (Technology Model): menetapkan manajemen teknologi, menjelaskan solusi dan pengembangan sistem dimasa yang mendatang, 5) Perspektif subkontraktor (Detailed Representations): dijelaskan ketetapan manajemen konfigurasi sistem dan implementasi pembangunan sistem, 6) Perspektif pengguna (Functioning Enterprise): menjelaskan manajemen operasi sitem dan evaluasi sitem berdasarkan fungsional sistem menurut perspektif user atau pengguna[16]. Dalam penelitian ini peneliti hanya membahas 4 perspektif yang ada pada zacham framework, yaitu perspektif planner, perspektif owner, perspektif designer dan perspektif builder. 


\section{HASIL DAN PEMBAHASAN}

Menghasilkan sebuah rancangan sistem yang dibutuhkan oleh lembaga, maka dibutuhkan suatu analisis data dan pemetaan masalah yang terjadi didivisi tersebut, dengan cara memetakan masalah yang terjadi maka menyusun masalah-masalah tersebut kedalam kerangka matrik zachman, sesuai dengan baris dan kolom sesuai dengan perspektif yang dibahas. Setelah semua baris dan kolom yang ada pada matrik tersebut terisi kemudian masingmasing hasil dari matrik tersebut akan diuraikan satu per satu menjadi sebuah simpulan pemetaan sesuai dengan perspektif yang ada pada kerangka zachman. Dibawah ini merupakan hasil dari pemetaan yang dilakukan menggunakan kerangka zachman yang dituangkan berupa table $6 \times 4$, dikarenakan penelitian ini hanya membahas 4 perspektif dari 6 perspektif yang ada pada zachman framework.

Tabel 1. Matrik Zachman sistem keuangan SDIT Andalusia

\begin{tabular}{|c|c|c|c|c|c|c|}
\hline & $\begin{array}{c}\text { Data } \\
\text { (What) }\end{array}$ & $\begin{array}{l}\text { Fungsi } \\
\text { (How) }\end{array}$ & $\begin{array}{l}\text { Jaringan } \\
\text { (Where) }\end{array}$ & $\begin{array}{l}\text { Orang } \\
\text { (Who) }\end{array}$ & $\begin{array}{l}\text { Waktu } \\
\text { (When) }\end{array}$ & $\begin{array}{c}\text { Motivasi } \\
\text { (Why) }\end{array}$ \\
\hline $\begin{array}{c}\text { Tujuan/Cakupan } \\
\text { (Perspektif } \\
\text { Perencana) }\end{array}$ & $\begin{array}{l}\text { Data Siswa, } \\
\text { Data Pos } \\
\text { Pembayaran, } \\
\text { Sumber } \\
\text { daya } \\
\text { Manusia } \\
\end{array}$ & $\begin{array}{c}\text { Proses } \\
\text { Penerimaan } \\
\text { dana dan } \\
\text { Pelaporan } \\
\text { dana }\end{array}$ & $\begin{array}{l}\text { Yayasan, } \\
\text { Lembaga } \\
\text { (SDIT } \\
\text { Andalusia) }\end{array}$ & $\begin{array}{c}\text { Kepala } \\
\text { Sekolah, } \\
\text { Bendahara, } \\
\text { TU }\end{array}$ & $\begin{array}{c}\text { Waktu } \\
\text { Penerimaan } \\
\text { dana dan } \\
\text { pelaporan } \\
\text { dana }\end{array}$ & $\begin{array}{l}\text { Visi dan } \\
\text { Misi } \\
\text { Lembaga }\end{array}$ \\
\hline $\begin{array}{c}\text { Model Bisnis } \\
\text { (Perspektif } \\
\text { Pemilik) }\end{array}$ & $\begin{array}{l}\text { Daftar } \\
\text { Entitas }\end{array}$ & $\begin{array}{c}\text { Proses bisnis } \\
\text { yang } \\
\text { berhubungan } \\
\text { dengan } \\
\text { penerimaan } \\
\text { dana dan } \\
\text { pelaporan } \\
\text { dana } \\
\end{array}$ & $\begin{array}{l}\text { Jaeringan } \\
\text { yang ada di } \\
\text { SDIT } \\
\text { andalusia }\end{array}$ & $\begin{array}{c}\text { Daftar } \\
\text { Sumberdaya } \\
\text { manusaia } \\
\text { internal atau } \\
\text { yang terkait }\end{array}$ & $\begin{array}{c}\text { Time } \\
\text { schedule } \\
\text { pembangunan } \\
\text { proyek sistem } \\
\text { informasi }\end{array}$ & $\begin{array}{c}\text { Alasan } \\
\text { Pengadaan } \\
\text { Sistem } \\
\text { Informasi }\end{array}$ \\
\hline $\begin{array}{c}\text { Model Sistem } \\
\text { Informasi } \\
\text { (Perspektif } \\
\text { designer) }\end{array}$ & $\begin{array}{c}\text { Class } \\
\text { Diagram }\end{array}$ & $\begin{array}{l}\text { Activity } \\
\text { diagram }\end{array}$ & $\begin{array}{c}\text { Desain } \\
\text { Jaringan } \\
\text { yang } \\
\text { diusulkan }\end{array}$ & $\begin{array}{c}\text { SDM yang } \\
\text { bertugas } \\
\text { dalam } \\
\text { pembangunan } \\
\text { system } \\
\end{array}$ & $\begin{array}{l}\text { Detail jadwal } \\
\text { perancangan } \\
\text { model system }\end{array}$ & $\begin{array}{l}\text { Aturan- } \\
\text { aturan } \\
\text { pembuatan } \\
\text { model }\end{array}$ \\
\hline $\begin{array}{c}\text { Model Teknologi } \\
\text { (Perspektif } \\
\text { Builder) }\end{array}$ & $\begin{array}{c}\text { Relasi antar } \\
\text { table }\end{array}$ & $\begin{array}{l}\text { Squance } \\
\text { Diagram }\end{array}$ & $\begin{array}{c}\text { Desain } \\
\text { jaringan } \\
\text { pengelolaan } \\
\text { data } \\
\text { keuangan } \\
\end{array}$ & $\begin{array}{l}\text { Gambaran } \\
\text { interface } \\
\text { aplikasi }\end{array}$ & $\begin{array}{l}\text { Detail jadwal } \\
\text { perancangan } \\
\text { aplikasi }\end{array}$ & $\begin{array}{l}\text { Aturan- } \\
\text { aturan } \\
\text { pembuatan } \\
\text { Desain }\end{array}$ \\
\hline
\end{tabular}

\subsection{Perspektif Perencanan}

Arsitektur kontekstual merupakan nama lain dari perspektif perencana yang menjelaskan proses penerimaan dana dan pelaporan keuangan yang ada di SDIT Andalusia Kota Sukabumi.

a.What (Data): Yang dijelaskan pada kolom ini ialah data data yang bersumber dari sudut pandang planner.

Hasil analisis dari data tersebut antara lain :

1. Data siswa yaitu data siswa yang sudah menjadi siswa SDIT Andalusia Kota Sukabumi

2. Data pos pembayaran yaitu pos penerimaan dana yang dikelompokan berdasarkan jenis pembayaran

3. Data pembayaran merupakan data pembayaran yang sudah diterima oleh bendahara sekolah

b.How (Proses): Yang dijelaskan pada kolom ini yaitu tentang proses pencatatan dana dari berbagai sumber pendapatan sesuai dengan pos-pos pembayaran yang ada di SDIT Andalusia dan segala jenis pengeluaran yang dilakukan dalam kegiatan yang ada di SDIT Andalusia .

c. Where (Lokasi): Yang di bahas pada kolom ini lokasi dari SDIT Andalusia Kota Sukabumi di jelaskan yaitu berada di Jl. Merbabu RT 03 RW 10 di Kelurahan Karangtengah Kecamatan Gunung Puyuh Kota Sukabumi Provinsi Jawa Barat.

d. Who (Orang): Yang dibahas pada kolom ini ialah tentang pelaku yang berperan penting dalam terjadinya proses penerimaan dan pengeluaran keuangan antara lain yaitu :

1. Pemilik Yayasan berperan sebagai penerima laporan akhir

2. Kepala Sekolah berperan sebagai menerima laporan awal

3. Staff Administrasi berperan sebagai mengolah data keuangan yang diterima oleh sekolah

4. Bendahara berperan sebagai melakukan penggantian pengeluaran operasional sekolah

5. Siswa melakukan pembayaran biaya pelayanan pendidikan

e. When (waktu): Yang dibahas pada Kolom ini yaitu tentang waktu pelaksanaan segala jenis pembayaran pada SDIT Andalusia Kota Sukabumi yang meliputi : 
1. Pembayaran biaya pelayanan pendidikan paling lambat setiap tanggal 15 dibulan tersebut, yang dilakukan oleh siswa.

2. Penggantian biaya operasional sekolah setiap 3 bulan sekali

f. Why (Motivasi): Yang dibahas pada kolom ini yaitu tentang visi dan misi SDIT Andalusia Kota Sukabumi, yang mana terangkum dalam pernyataan-pernyataan berikut :

1. Visi SDIT Andalusia ialah "Membentuk generasi qurani yang berakhlaq mulia dan berprestasi serta memiliki wawasan global berbasiskan ilmu pengetahuan dan teknologi”.

2. Misi SDIT Andalusia yang ingin dicapai yaitu : a) Terwujudnya pengamalan Al-Qur`an dan sunah Rosul dalam kehidupan sehari-hari, b) Membangun sistem pendidikan yang berorientasi pada siswaagar lebih kreatif, inovatif dan mampu berekplorasi dalam bingkai kaidah islam, c) Menerapkan pembiasaan nilainilai akhlak mulia dilingkungan sekolah dan rumah, d) Terbentuknya lembaga pendidikan yang amanah, profesonal dan aktif menjalin kemitraan, e) Menghasilkan lulusan yang memiliki kemampuan akademis tinggi yang terintegrasi dengan nilai-nilai islam yang kuat, f) Tersedianya pendidikan dan tenaga pendidikan yang professional, ramah dan berkarakter, dan g) Terciptanya lingkungan belajar yang menyenangkan dan islami.

\subsection{Perspektif Pemilik}

Pada perspektif pemilik atau owner akan menjabarkan mengenai sebuah sistem informasi yang diusulkan dan seperti apa sistem itu berjalan nantinya dengan sistem informasi dan teknologi yang tersedia, sehingga memberikan gambaran mengenai sistem yang sesuai dengan kondisi proses bisnis yang ada dilembaga.

a.What (Data): Yang dijelaskan pada kolom ini ialah data-data yang bersumber dari sudut pandang owner. Hasil analisis dari data tersebut berupa entitas antara lain :

1. Data_siswa yaitu data siswa yang sudah menjadi siswa SDIT Andalusia Kota Sukabumi

2. Pembayaran_siswa yaitu pembayaran kewajiban siswa yang akan dilakukan oleh siswa seperti pembayaran spp, dana social pembangunan dan lain lain.

3. Data_pos_pembayaran yaitu pos penerimaan dana yang dikelompokan berdasarkan jenis pembayaran

4. Data_pembayaran merupakan data pembayaran yang sudah diterima oleh bendahara sekolah yang telah di input oleh staff penerimaan pembayaran.

b.How (Proses): Yang dijelaskan pada kolom ini yaitu tentang proses penerimaan dana dijelaskan dengan bentuk Flow Chart Diargam yaitu flowchart penerimaan dana.

c.Where (Lokasi): Yang dijelaskan di kolom ini adalah jaringan yang ada di SDIT Andalusia yang digunakan sehari-hari, dan belum terdapat suatu server data sehingga informasi dari setiap tidak terintegrasi dengan baik.

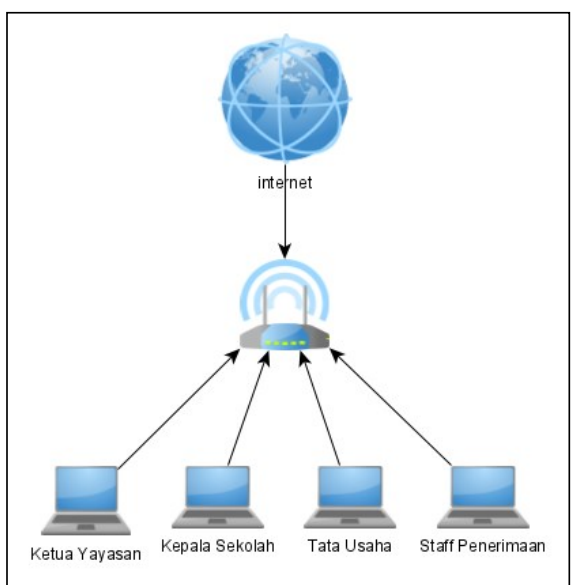

Gambar 3. Jaringan yang ada di SDIT Andalusia

d.Who (Orang): Yang dijelaskan dikolom ini adalah siapa saja sumber daya manusia yang berperan dalam proses penerimaan dana :

1. Siswa sebagai sumber dana yang diterima

2. Staff Administrasi sebagai penerima dan penginput dana yang masuk

3. Bendahara sebagai penyusun laporan yang dihasilkan dari proses input penerimaan dana 
4. Kepala Sekolah sebagai penerima laporan awal sebelum dilaporkan kepada ketua yayasan

5. Ketua Yayasan sebagai owner yang menerima laporan keuangan akhir

e.When (Waktu): Yang dijelaskan dalam kolom ini yaitu waktu terjadinya kegiatan pembangunan sistem informasi keuangan.

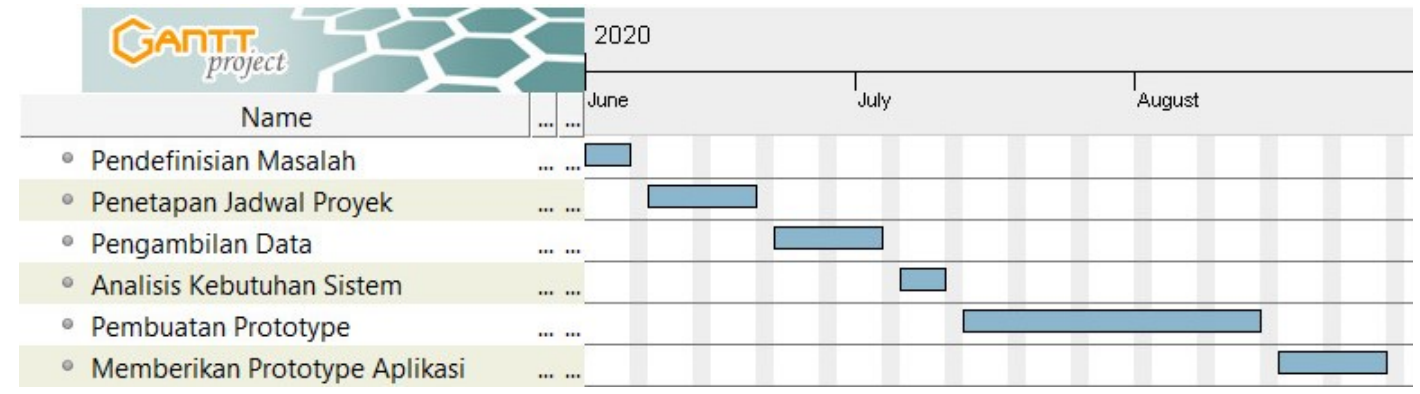

Gambar 4. Jadwal kegiatan pembangunan sistem

f. Why (Motivasi): Yang dijelaskan dalam kolom ini adalah tujuan yang ingin dicapai oleh lembaga mengenai tujuan akhir dari rancangan alpikasi sistem yang dibuat, diantaranya yaitu :

1. Terwujudnya pencatatan administrasi yang terkelola dengan baik sehingga proses bisnis yang dijalankan menjadi lebih efektif dan efisien.

2. Memecahkan masalah masalah yang terjadi dalam pelaksanaan penerimaan dana seperti kesalahan catat dan input ganda atau redudansi data

3. Membangun dan mengimplementasikan teknologi informasi untuk menyelaraskan dengan visi dan misi lembaga.

4. Mampu memberikan output laporan keuangan yang tepat sehingga meningkatkan kualitas kinerja dan memberikan dampak positif dalam penilaian dari pihak yayasan.

\subsection{Perspektif Designer}

Pada perspektif designer atau model sistem informasi yang akan menjadi dasar sebagai rancangan sistem yang akan digunakan berupa model logic beserta kebutuhan lainnya harus memperlihatkan elemen data, aliran proses dan fungsi yang menggambarkan entitas

a. What (Data) : Dalam kolom ini memberikan gambaran relasi antar entitas secara detail yang dituangkan dalam bentuk Entity Relation Diagram (ERD).

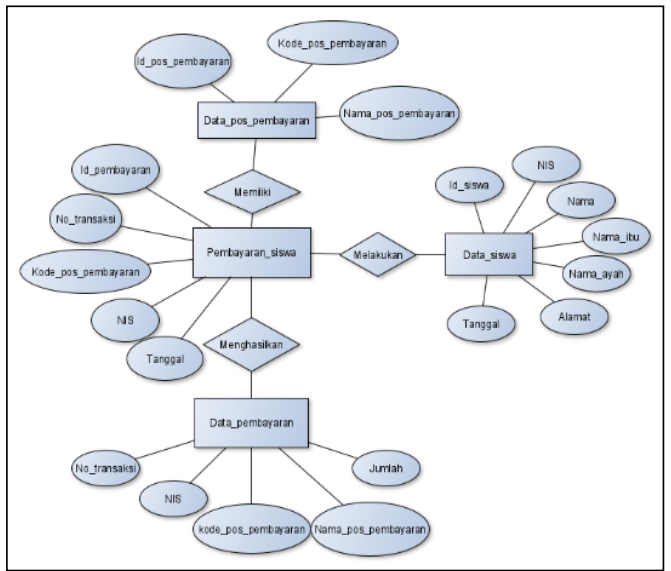

Gambar 5. Rancangan ERD

b.How (Proses) : Berisi arsitektur aplikasi yang menggambarkan usulan sistem informasi. Pada kolom ini menjelaskan aktivitas prilaku sistem berupa activity diagram, diantaranya :

1. activity diagram login (gambar 6)

2. activity diagram input pembayaran (gambar 7)

3. activity diagram penampilan laporan keuangan (gambar 8) 


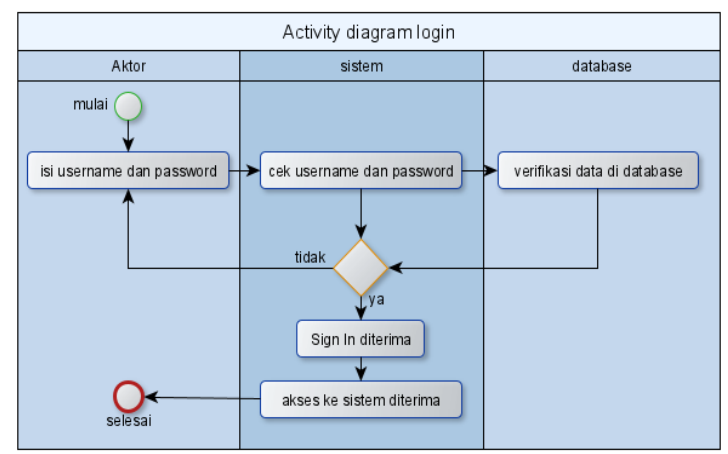

Gambar 6. Activity diagram login

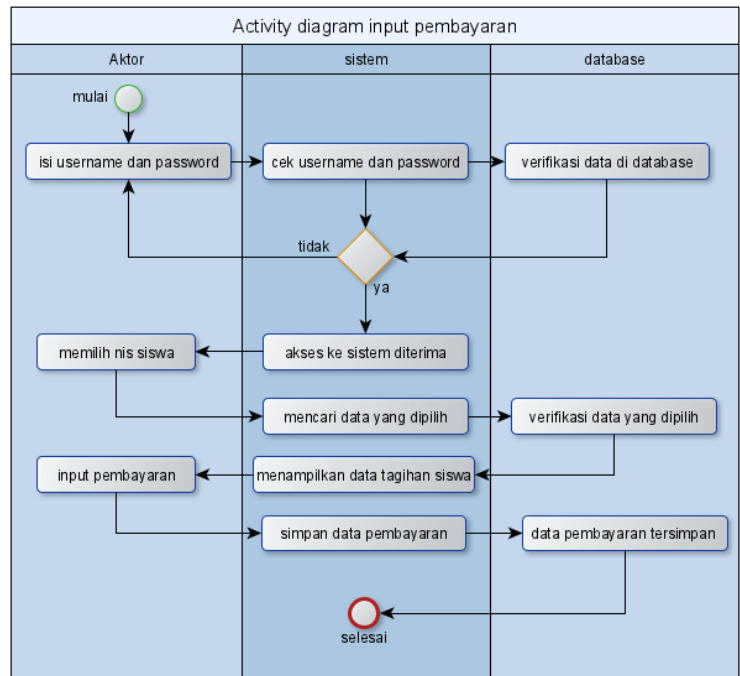

Gambar 7. Activity diagram input pembayaran

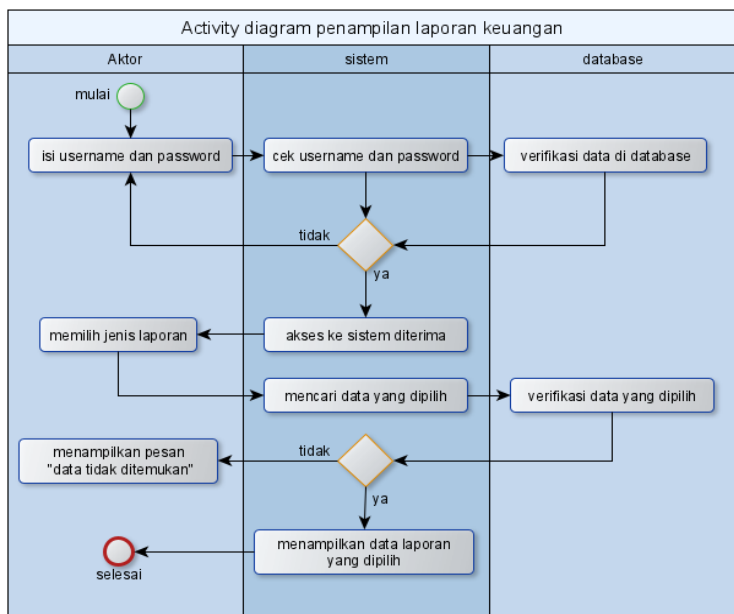

Gambar 8. Activity diagram penampilan laporan

c.Where (Lokasi) : Yang dijelaskan pada kolom ini yaitu berisi model logis dari keterhubungan node pada suatu jaringan dan gambaran dalam bentuk topologi jaringan. Uusulan rancang bangun jaringan internet yang akan digunakan oleh SDIT Andalusia sebagai rangkaian jaringan dengan menambahkan web server sebagai sumber data yang akan digunakan dikemudian hari untuk menyimpan database sistem informasi yang dibuat. 


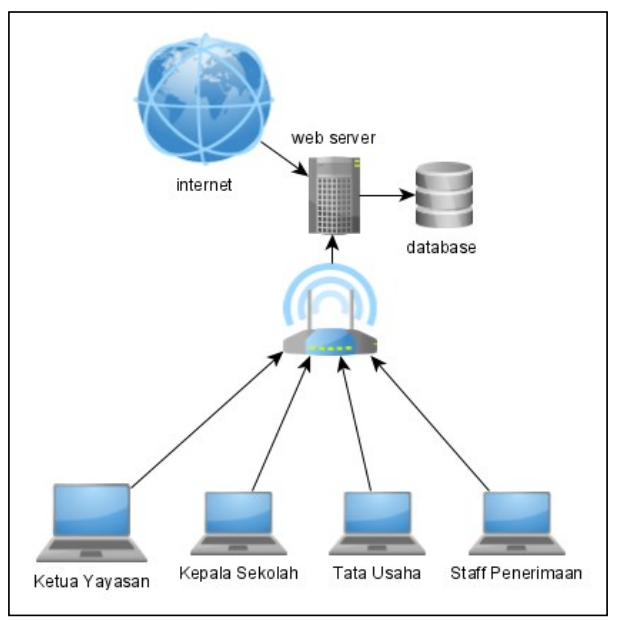

Gambar 9. Jaringan yang diusulkan

d.Who (Orang) : Yang dijelaskan dalam kolom ini yaitu sumber daya manusia yang ditugaskan untuk membangun dan mengelola sistem informasi manajemen keuangan yang akan dibuat di SDIT Andalusia, yang berguna untuk mensukseskan proses pembangunan sistem diantaranya :

1. Staff Penerimaan sebagai sumber daya manusia yang bertugas sebagai penerima dan penginput data pembayaran yang dilakukan siswa dan memberikan informasi mengenai proses pembayaran dan proses dana masuk.

2. Bendahara sebagai sumber daya manusia yang bertugas sebagai pengecek alur dana masuk dan keluar dari lembaga dan sebagai penyusun laporan keuangan serta berperan sebagai pemberi informasi mengenai alur proses pelaporan keuangan kepihak Yayasan.

3. Programer web aplikasi sebagai sumber daya manusia dari external lembaga yang bertugas sebagai perancangan aplikasi sistem informasi yang dibutuhkan oleh lembaga.

4. Teknisi hardware dan jaringan sebagai sumber daya manusia yang bertugas sebagai perancang jaringan yang akan digunakan di lembaga dikemudian hari.

e.When (Waktu): Yang dijelaskan pada kolom ini yaitu waktu atau detail jadwal beberapa perancangan hal yang menunjang terbentuknya sebuah sistem informasi keuangan yang diinginkan diantaranya :

1. Penentuan entitas

2. Perancangan usecase diagram

3. Perancangan Activity Diagram

4. Perancangan database

5. Perancangan antar muka

GAMT
Name

Gambar 10. Detail jadwal perancangan

f. Why (Motivasi): Yang dijelaskan pada kolom ini yaitu tentang aturan-aturan yang berlaku dan ditetapkan dalam proses perancangan sistem informasi seperti halnya :

1. Batasan entitas seperti atribut, tipe data dan primary key

2. Nilai dari atribut

3. Hak akses setiap user 


\subsection{Perspektif Builder}

Pada bagian ini menjelaskan perancangan awal sebuah sistem informasi yang diusulkan berupa susunan model data fisik yang harus disesuaikan dengan model sistem informasi seperti perangkat input/output atau kebutuhan teknologi lainnya.

a. What (Data): Dalam kolom ini berisi tentang relasi antar table berisi model data fisik yang direpresentasikan sebagai tabel beserta atribut yang akan digunakan untuk membangun sistem yang akan dibuat. Dibawah ini merupakan gambaran sederhana dari relasi antar tabel yang dibutuhkan dalam sistem ini.

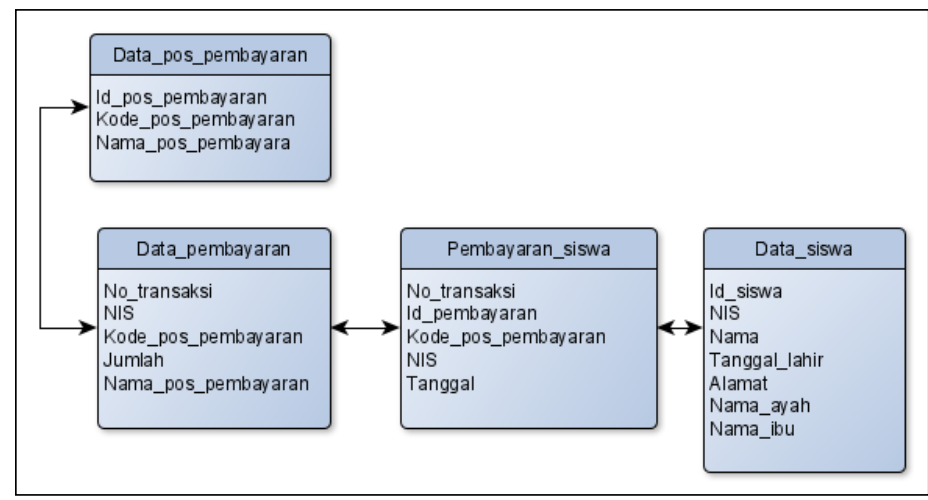

Gambar 11. Relasi antar tabel

b.How (Proses): Dalam kolom ini dijelaskan permodelan proses yang terjadi didalam sistem informasi ke dalam sequence diagram berisi input yang akan diolah dan output yang dihasilkan oleh sistem.

c. Where (Lokasi): Memberikan gambaran fisik dari kebutuhan teknologi SDIT Andalusia. Kebutuhan tersebut berupa perangkat keras, perangkat lunak dan perangkat lunak sistem (sistem operasi). Dalam kolom ini dijelaskan peta jaringan pengelolaan data yang akan di berlakukan pada aplikasi sistem yang akan berlaku di SDIT Andalusia.

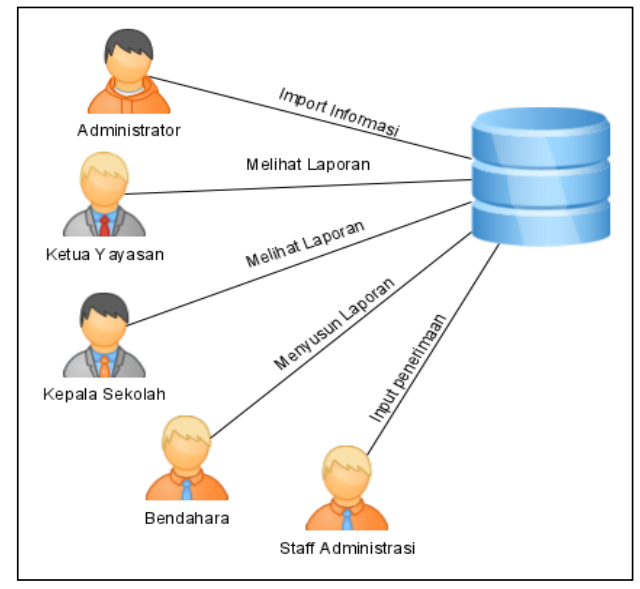

Gambar 12. Jaringan pengelolaan data

d.Who (Orang): Pada bagian kolom ini menampilkan antarmuka aplikasi sistem yang mengacu pada pelaku atau pemakai sistem.

e.When (waktu): Jadwal perancangan pembuatan aplikasi dimuat dikolom ini yang bertujuan untuk menentukan waktu dan target pembuatan aplikasi sistem informasi dimulai dari proses pembuatan database, pembuatan antar muka desain dan pembuatan kode program aplikasi.

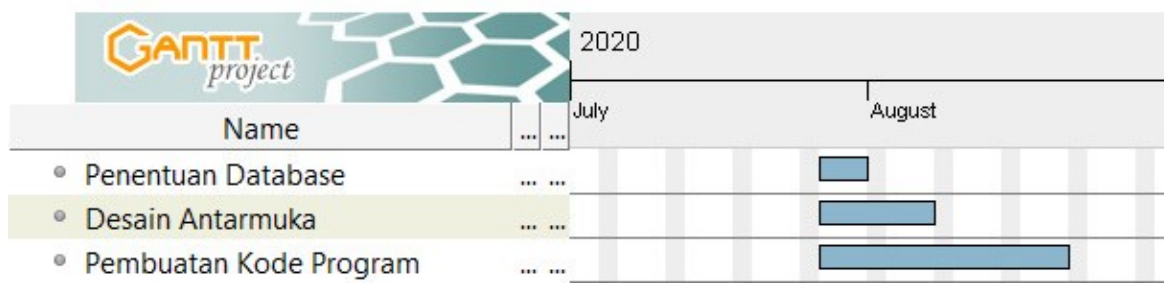

Gambar 13. Jadwal perancangan aplikasi 
f. Why (Motivasi): Pada kolom ini menjelaskan perangkat-perangkat apasaja yang digunakan saat membuat aplikasi hingga selesai seperti halnya : Sofware yang digunakan bersifat open source karena untuk mengurangi biaya yang terlalu besar maka perangkat lunak yang digunakan antara lain yaitu :

1. Software database menggunakan MySQL dan diolah melalui Phpmyadmin

2. Bahasa pemograman menggunakan PHP dan HTML

3. Desain tataletak aplikasi menggunakan metode CSS

4. Aplikasi web servernya menggunakan Apache.

\section{KESIMPULAN}

Berdasarkan rangkaian penelitian mengenai zachman framework diatas menunjukan bahwa dalam proses penerapan zachman framework diharuskan melakukan observasi langsung terhapat objek yang diteliti dan diantara hasil penelitian yang didapat penulis menyimpulkan beberapa point yang dapat diambil diantaranya yaitu :

1) Tujuan dari penerapan zachman framework pada sebuah perancangan sistem informasi merupakan metode yang bisa dikatakan tepat karena untuk menciptakan arsitektur yang sesuai kebutuhan oleh sebuah lembaga atau organisasi diperlukan berbagai pandangan yang sesuai dengan apa yang dibutuhkan oleh masing-masing bagian yang ada dilembaga atau oraganisasi tersebut, adapun yang diatasi oleh penggunaan zachman framework ini diantaranya arsitektur data, fungsi, jaringan, sumber daya manusia, waktu dan motivasi sehingga bisa membantu menyelesaikan masalah lebih yang dihadapi;

2) Aplikasi sistem yang direncanakan dengan matang merupakan salah satu cara untuk meningkatkan efektivitas dalam menjalankan suatu proses bisnis yang ada dalam lembaga seperti dalam proses pencatatan dan penulisan laporan keuangan yang merupakan suatu kegiatan bisnis yang sangat penting karena menyangkut pendanaan segala kegiatan yang dilakukan oleh lembaga dan suatu organisasi yang memiliki sistem informasi yang baik selain dapat meningkatkan penilaian positif dari stakeholder lembaga juga bisa meningkatkan kinerja dalam lembaga atau organisasi ini;

3) Blue print atau rancangan aplikasi yang dihasilkan dalam penelitian ini diharapkan bisa menjadi acuan dalam pembuatan sistem aplikasi keuangan dan bisa mengatasi masalah yang terjadi dalam pengelolaan keuangan yang ada dilembaga sehingga bisa sesuai dengan apa yang dibutuhkan oleh divisi keuangan dalam menjalankan kegiatan penerimaan dan pengelolaan keuangan lembaga, mengurangi kesalahan kesalahan yang sering timbul seperti redudansi data dalam pencatatan dan penyusunan laporan keuangan dan menambah efektivitas kinerja dalam divisi keuangan sehingga lebih terorganisasi dengan baik laporan yang dihasilkan, dan menghasilkan laporan informasi keuangan yang efisien dan mudah dimengerti oleh pemilik yayasan.

4) Kerangka zachman atau zachman framework sangat memberikan peluang terjadinya proses pengembangan sistem informasi dimasa mendatang dengan memperhatikan perspektif owner sebagai landasan berpikir, dikarenakan keinginan owner yang digali dalam zachman framework ini memberikan gambaran sistem informasi yang dibutuhkan oleh lembaga tersebut, sehingga pengembangan sistemnya tidak akan keluar dari tujuan dan cita cita owner atau pemilik lembaga maka sistem yang akan dibangun akan sesuai dan cocok dengan proses kerja dari organisasi tersebut.

5) Adapun untuk pengembangan penelitian lebih lanjut bisa digunakan kerangka zachman secara utuh dengan menambahkan perspektif subkontraktor dan perspektif pengguna agar lebih terstruktur dan terrencana dalam pengembangan sistem ini, sehingga sistem yang dibangun akan semakin jelas dan hasilnya akan semakin memuaskan dan adanya pandangan dari pengguna sistem akan menjadikan aplikasi sistem akan mendapatkan evaluasi sistem apakah sudah cocok untuk digunakan oleh lembaga, dan dapat menjadi suatu asupan perbaikan untuk sistem mendatang.

\section{UCAPAN TERIMA KASIH}

Penulis mengucapkan terima kasih kepada Tuhan Yang Maha Esa karena atas kehendak-Nya lah penulis dapat menyelesaikan jurnal ini. Terimakasih juga penulis ucapkan kepada keluarga dan rekan seperjuangan yang telah mendukung baik moral maupun finansial kepada penulis.

\section{REFERENCES}

[1] Rifa'i dan Fadhli, Manajemen Organisasi, vol. 53, no. 9. 2013.

[2] F. Andalia and E. B. Setiawan, "Pengembangan Sistem Informasi Pengolahan Data Pencari Kerja Pada Dinas Sosial Dan Tenaga Kerja Kota Padang," Komputa : Jurnal Ilmiah Komputer dan Informatika, vol. 4, no. 2, pp. 93-97, 2015, doi: 10.34010/komputa.v4i2.2431. 
[3] G. . McLeod, Raymond \& Schell, Management Information System - Sistem Informasi Manajemen. 2012.

[4] A. Y. Andi Mardiana Paduppai, Wahyu Hardyanto, Agus Hermanto, "Pengembangan Sistem Informasi Manajemen," Seminar Nasional Pascasarjana 2019, pp. 84-89, 2019.

[5] G. Adillah, "Manajemen Keuangan Sekolah,” Manajer Pendidikan, vol. 10, no. 4, pp. 343-346, 2016, doi: 10.31227/osf.io/m2huz.

[6] R. Khoerunnisa, "Implementasi Zachman Framework Pada Arsitektur Sistem Informasi Inventaris Berbasis Web Service (Studi Kasus: Yayasan ...," Jursistekni.Nusaputra.Ac.Id, [Online]. Available: https://jursistekni.nusaputra.ac.id/article/view/11.

[7] J. A. Zachman, “The zachman framework for enterprise," Zachman International, p. 38, 2003.

[8] Lasimin, Kusrini, and E. T. Lutfi, "Enterprise Architecture Planning Manajemen Kampus Di Stikesal-Irsyad AlIslamiyyah Cilacap,” Jurnal Penelitian dan Pengabdian Kepada Masyarakat UNSIQ, no. 3, pp. 219-228, 2016.

[9] M. Adhani, L. A. Abdillah, and Q. Widayati, "Analisa dan perancangan sistem informasi penerimaan siswa baru dan pembayaran spp menggunakan zachman framework," Seminar Nasional Informatika, 2015.

[10] S. Pinjam and J. Manunggal, "Penerapan Framework Zachman Dalam Merancang Blueprint ( Arsitektur ) Sistem Informasi Administrasi Pada Koperasi Design of Administration Information System on Koperasi,” no. x, pp. 1-12, 2012.

[11] J. Raco, "Metode penelitian kualitatif: jenis, karakteristik dan keunggulannya," 2018, doi: 10.31219/osf.io/mfzuj.

[12] T. Nempung, T. Setiyaningsih, and N. Syamsiah, "Otomatisasi Metode Penelitian Skala Likert Berbasis Web," no. November, pp. 1-8, 2015.

[13] H. Hasanah, "TEKNIK-TEKNIK OBSERVASI (Sebuah Alternatif Metode Pengumpulan Data Kualitatif Ilmu-ilmu Sosial)," At-Taqaddum, vol. 8, no. 1, p. 21, 2017, doi: 10.21580/at.v8i1.1163.

[14] N. H.-I. J. P. dan Informasi and undefined 2014, “Penelitian Kepustakaan,” vol. 0, no. 01, pp. 36-39, 2011.

[15] R. Irfanto and J. Fernandes Andry, "1 Perancangan Enterprise Architecture Menggunakan Zachman Framework (Studi Kasus: Pt.Vivamas Adipratama)," Perancangan Enterprise Architecture Menggunakan Zachman Fr, no. November, pp. 1-2, 2014.

[16] R. Rosmiati, "Perencanaan Sistem Informasi Akademik Menggunakan Zachman Framework," Jurnal SAINTEKOM, vol. 7, no. 1, p. 13, Apr. 2017, doi: 10.33020/saintekom.v7i1.18. 